\title{
МЕТОДИКА ПІДГОТОВКИ І ЧИТАННЯ ЛЕКЦІЙ 3 ХІРУРГІЧНОЇ СТОМАТОЛОГІї
}

\author{
Н. Б. Кузняк, С. В. Ткачик, Я. В. Горицький \\ Буковинський державний медичний університет
}

\section{METHODS TO PREPARE AND DELIVER LECTURES ON SURGICAL STOMATOLOGY}

\author{
N. B. Kuzniak, S. V. Tkachyk, Ya. V. Horytskyi \\ Bukovynian State Medical University
}

\begin{abstract}
Ефективність лекції певною мірою залежить від підібраного фактичного матеріалу, який грунтується на власному погляді викладача, його самостійному трактуванні. Лекція покликана не тільки формувати у студентів основи знань 3 хірургічної стоматології, а й визначати напрями, зміст і характер інших видів навчальних занять та самостійної роботи.
\end{abstract}

The efficacy of lectures to some extent depends on the information selected which is based on a personal view of the teacher and his individual perception. The lecture should not only give the students some foundations on Surgical Stomatology, but also to determine the directions, content and character of other kinds of educational and independent student's work.

Вступ. Лекції з дисциплін, що викладаються кафедрою, є структурованими і містять вступ, основну частину і висновки. Вступ є коротким і виразним. У ньому лектор зосереджує увагу студентів на предметі лекції, ії цілях і завданнях, прикладному значенні. Важливим також є вміння викликати інтерес до навчального матеріалу, відновити у пам'яті студентів основний матеріал з попередніх лекцій, дати час підготуватися до сприймання лекції. Більша частина лекції відводиться розкриттю основного змісту, передбаченого планом лекції. Завершується виклад лекції висновком.

Ефективність лекції значною мірою залежить від чіткості та послідовності розгортання їі змісту. Цьому сприяє план, який повідомляють на початку лекції [1].

Основна частина. Обсяг і зміст матеріалу лектори підбирають відповідно до навчальної програми 3 навчальної дисципліни. Лекції не охоплюють весь програмний матеріал з теми, щоб у студента не склалося враження, що конспект лекції є єдиним джерелом, потрібним для пізнання науки. Окрім того, перенасичена інформацією лекція послаблює процес запам'ятовування необхідних знань, перешкоджає формуванню у слухачів суб' єктивної системи у знаннях, навіть якщо об' єктивно (в лекції) вона існує. Тому частину програмного матеріалу виділяють для самостійного опрацювання. При цьому важливо привчити студентів звертатися до програми навчальної дисципліни під час ії вивчення.
У процесі підготовки до лекції викладачі з'ясовують співвідношення іiї змісту зі змістом наявних підручників та навчальних посібників 3 дисципліни. Зміст лекції грунтується на власному погляді викладача на матеріал, його самостійному трактуванні, а не дублюванні підручника чи посібника.

Запорукою ефективності лекції $є$ вдало підібраний фактичний матеріал. Однак перевантаження лекції фактами нерідко призводить до зниження іiї наукової цінності [2].

3 огляду на це лекції вибудовують на матеріалі, який буде поглиблюватися і розширюватися на практичних та семінарських заняттях.

Під час проведення лекцій викладачі кафедри дотримуються певних вимог: доведення до студентів мети лекції і належне іiі мотивування; доступність i науковість викладу; включення механізму зворотного зв' язку; повторення важливих теоретичних положень; завершення кожного питання лекції підсумком і мотивованим переходом до наступного; вміння $\mathrm{i}$ здатність змусити себе слухати; емоційність викладу (є засобом мобілізації і підтримання уваги студентів. Емоційність досягається насамперед чіткою, живою, образною, інтонованою мовою викладача. Їй сприятимуть також афоризми, вдалі аналогії, ідіоматичні вирази); налагодження живого контакту; створення проблемних ситуацій.

Важливим питанням у роботі студента-медика під час лекції $€$ конспектування. Воно корисне з огляду

(c) Н. Б. Кузняк, С. В. Ткачик, Я. В. Горицький 
на те, що допомагає навчитися одночасно робити кілька справ: слухати, писати, аналізувати, розмірковувати; під час записів на лекції у студента одночасно працює кілька аналізаторів - він слухає, дивиться, пише. Така комплексна діяльність сприяє кращому засвоєнню навчального матеріалу та інтенсивнішому розвитку наукового мислення майбутнього лікаря-стоматолога.

Слухання лекцій буде ефективнішим, якщо студенти самостійно заздалегідь готуватимуться до наступної лекції за підручником. За такої умови вони перестануть механічно конспектувати все, що викладач дає під час лекції [3]. Адже механічне записування тексту лекції заважає слухати і аналізувати іiі за змістом, відокремлювати в ній головне від другорядного. Студентам, особливо перших курсів, варто давати план кожної наступної лекції. Це активізує пізнавальні сили, сприяє зосередженню уваги.

Також важливим для лектора є вміння використовувати можливості свого голосу. Так, несприятливо діє на студентів тихе і монотонне читання, від чого настає швидка втомлюваність слухачів: студенти або перестають слухати лекцію, або вольовими зусиллями змушують себе стежити за нею. У мові лектора студенти повинні відчувати певні орієнтири для сприймання [4].

Важливим засобом для підтримання уваги студентів під час лекції є використання пауз. Їх роблять перед повідомленням важливих наукових положень, щоб загострити увагу студентів.

Зважають також і на темп читання лекції: при надто швидкому темпі студент не встигає стежити за роздумами викладача й записувати важливі положен-

\section{Література}

1. Болюбаш Я. Я. Організація навчального процесу у вищих закладах освіти / Я. Я. Болюбаш. - К. : ВВП “Компас", 2001.

2. Сисоєва О. О. Основи педагогічної творчості вчителя : навчальний посібник / О. О. Сисоєва. -К., 1998.

3. Вонсович В. Проблема якості знань студентів та їі трактування у педагогіці / В. Вонсович // Наукові записки ТДП. Педагогіка.-2002.-Вип. 3. ня лекції. Якщо ж темп надто повільний, то студенти відволікаються.

У процесі читання лекції важливо активізувати розумову діяльність студентів. Для цього використовують різноманітні прийоми: запитання, у т. ч. риторичні; уміння викликати у студентів сумнів; поєднання теоретичних положень 3 важливою для студентів практикою; використання у викладі найновіших відкриттів та здобутків медичної науки; забезпечення студентів мікроконспектом до наступної лекції, який готував би їх до їі сприймання, розуміння і здійснення обміну думками у “спровокованій” дискусії; проведення "блискавичного" дослідження методом “мозкового штурму” та створення на лекції проблемних ситуацій тощо [5].

Завершення підготовки викладача до лекції має бути у певний спосіб оформлене: конспект чи повний текст лекції. Однак це певною мірою “прив” язує” викладача до них під час лекції, викликає бажання прочитати іiі за цим матеріалом, не вносячи ніяких змін. Доцільніше готувати впорядковані записи. За таких умов завжди $є$ можливість щось додати, вилучити або змінити, легко знайти потрібний матеріал під час лекції [6].

Висновок. Отже, рівень підготовки викладачів кафедри хірургічної стоматології до кожної лекції передусім визначається його науковою, методичною та загальною культурою. Однак яким би високим не був рівень викладача, він зобов'язаний готуватися до кожної лекції. Зумовлено це тим, що стоматологія інтенсивно розвивається, з'являються нові знання, якими потрібно поповнювати власний багаж. Удосконалюється постійно і методика викладання.

4. Шестак Н. В. Высшая школа: технологии обучения / Н. В. Шестак.-М., 2000.

5. Мороз О. Г. Навчальний процес у вищій школі / О. Г. Мороз. -К., 2001.

6. Коваленко О. С. Проблеми методичної підготовки викладачів спеціальних дисциплін / О. С. Коваленко // Педагогіка іпсихологія. - 1996. -№4. 